\title{
Developmental Changes in the Parotid Salivary Gland of Prenatal Buffalo: An Ultrastructural Study
}

\author{
Cambios en el Desarrollo de la Glándula Salival de la Parótida \\ de Búfalo Prenatal: Un Estudio Ultraestructural
}

Aman Deep Singh $^{1} \&$ Opinder Singh ${ }^{2}$

SINGH, A. D. \& SINGH, O. Developmental changes in the parotid salivary gland of prenatal buffalo: An ultrastructural study. Int. J. Morphol., 35(4):1332-1336, 2017.

SUMMARY: The present study was undertaken to elucidate ultrastructural changes in development of parotid salivary gland of buffalo during different stages of prenatal life. The ultrastructural studies revealed that the cytoplasm of acinar cells was filled with mitochondria, rough endoplasmic reticulum and Golgi complex in mid and late foetal age groups. Medium electron dense secretory granules first appeared in the acinar cells of parotid gland at $30 \mathrm{~cm}$ CVRL (141st day). However, at $49.5 \mathrm{~cm}$ CVRL (185 $5^{\text {th }}$ day) two types of electron dense granules were identified on basis of granule density viz., dark and light. The dark electron dense granules were more in number, whereas light granules were comparatively less having electron lucent content within them was identified. The mean diameter of dark and light granules was measured about $0.45 \pm 0.1 \mu \mathrm{m}$ and $0.30 \pm 0.1 \mu \mathrm{m}$, respectively, which showed that the dark granules were comparatively larger in size. The secretory granules were increased in number during the late foetal age group. The myoepithelial cells were located at the base of the acinar cells as well as intercalated and striated ducts, and were stellate in shape. The ultrastructure of myoepithelial cell revealed parallel stream of myofilaments in the cytoplasm and its processes. Lipofuscin pigments were also observed in between the acinar cells of parotid gland.

KEY WORDS: Buffalo; Electron microscopy; Parotid gland; Prenatal.

\section{INTRODUCTION}

The parotid salivary gland being one of the major salivary glands of domestic animals contributes to substantial amount of saliva secreted into the mouth. Its function has multifaceted dimension in digestion, as it provide lubrication for eating and supply saliva for $\mathrm{pH}$ buffering (Moghaddam et al., 2009). The secretion, saliva, contains water, various enzymes, mucopolysaccharides and lubricating glycoproteins. In general, the major salivary glands of the herbivores are better developed than those of the carnivores. Saliva is secreted into the oral cavity via a series of ducts in the ductal system.

Dysfunction of salivary secretion (hyposalivation) causes xerostomia (dry mouth) and sequentially leads to severe dental caries as well as oral mucosal disorders (Featherstone, 2000). This paucity and the precious role of parotid salivary gland in digestion prompted to study the histogenesis which may be serving as a tool in future research on stem cell analysis of primordia of salivary gland. The study of prenatal development is prerequisite to understand the normal developmental biology of an organ.

The documentation of normal foetal growth can serve as a guide for understanding the consequence of harmful influences at various stages of gestation. Various prenatal as well as postnatal studies have been done on salivary glands of cat (Knospe \& Böhme, 1995), human (Chi, 1996), rat (Wolff et al., 2002), pig (Pospieszny et al., 2010), sheep (Singh et al., 2015) and buffalo (Singh \& Singh, 2017) however, there is no detailed information about the ultrastructural studies of buffalo parotid gland during prenatal development, therefore, the present work was aimed to observe the ultra-structural changes in the parotid salivary gland of prenatal buffalo. 


\section{MATERIAL AND METHOD}

The present study was conducted on parotid salivary gland of thirty-six buffalo foetuses, during different stages of prenatal development. Immediately after collection, the foetuses were measured for their curved crown rump length (CVRL) in centimetres with a calibrated inelastic thread. The approximate age of foetuses was calculated by using the following formula given by Soliman (1975) in buffalo.

$$
\begin{aligned}
& \mathrm{Y}=28.66+4.496 \mathrm{X}(\mathrm{CVRL}<20 \mathrm{~cm}) \\
& \mathrm{Y}=73.544+2.256 \mathrm{X}(\mathrm{CVRL} \geq 20 \mathrm{~cm})
\end{aligned}
$$

Where $\mathrm{Y}$ is age in day(s) and $\mathrm{X}$ is curved crown rump length (CVRL) in $\mathrm{cm}(\mathrm{s})$. Depending upon CVRL, foetuses were divided into three groups with a minimum of twelve samples in each group:

Group I : CVRL between $0-20 \mathrm{~cm}$

Group II : CVRL $>20$ to $40 \mathrm{~cm}$

Group III : CVRL $>40 \mathrm{~cm}$

Immediately after measuring CVRL, the tissue samples, collected from parotid salivary gland of buffalo foetuses, were thoroughly washed in phosphate buffer saline solution ( $\mathrm{pH} \mathrm{7.4)}$ and were trimmed to $1 \mathrm{~mm}^{3}$ size. These samples were fixed in Karnovsky's fixative (2.5 per cent glutaraldehyde and 2 per cent paraformaldehyde in $0.1 \mathrm{M}$ phosphate buffer solution) for 8-12 hours and their secondary fixation were done in 2 per cent osmium tetraoxide for 2 hours. Subsequently, tissue samples were dehydrated, cleared, infiltrated, embedded and polymerized. The ultrathin sections of 70-90 nm were cut and stained with uranyl acetate for 15 minutes followed by lead citrate for 10 minutes (Bozolla \& Russell, 1992). The grids with sections were examined under transmission electron microscope for detailed study.

\section{RESULTS AND DISCUSSION}

The terminal buds were in the form of cell clusters and contained glycogen rich inner luminal and outer myoepithelial precursor cells at $11.5 \mathrm{~cm}$ CVRL ( $80^{\text {th }}$ day). The primary duct was double layered and consisted of inner glycogen rich ductal cells and outer myoepithelial precursor cells. At $15.5 \mathrm{~cm}$ CVRL (98 ${ }^{\text {th }}$ day), more glycogen and mitochondria were noticed in the apical cytoplasm of the cells of both striated and interlobular ducts of prenatal parotid gland. Increased rough endoplasmic reticulum and the development of the Golgi complexes were noticed during differentiation of terminal buds into acini. The cytoplasmic organelles were poorly developed in the cells of terminal tubules, which was in conformity with the finding of Yaku (1983) in human beings. Lumen formation was first observed in the primary duct when compared to terminal buds.

The cells of the terminal buds contained many folding of basal plasma membrane and possessed short microvilli on luminal side at $30 \mathrm{~cm}$ CVRL (141 $1^{\text {st }}$ day). Secretory granules first appeared in the cell apex of the luminal acinar cells at this stage of prenatal life (Fig. 1). The luminal diameter of acini was larger and had more of secretory granules than the intercalated ducts. The rough endoplasmic reticulum elongated into spiral form in the infranuclear cytoplasm of the epithelial cells. However, in rats, electron dense secretory granules were reported to be formed in acinar cells of parotid gland at one day after birth (Redman \& Sreebny, 1970).

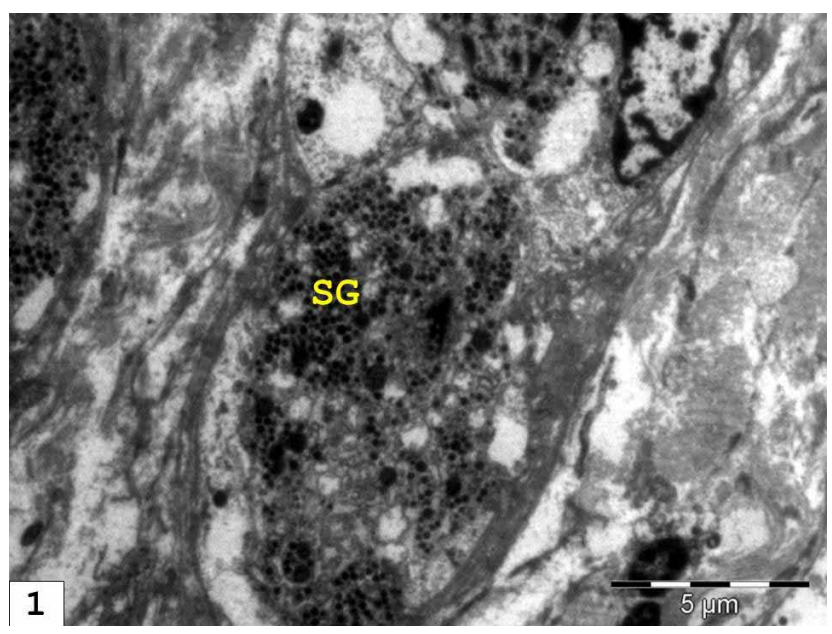

Fig. 1. Transmission electron micrograph of parotid salivary gland of $30 \mathrm{~cm}$ CVRL ( $141^{\text {st }}$ day) buffalo foetus showing appearance of medium electron dense secretory granules (SG) in the acinar cells. 1300x

The cytoplasm of acinar cells was filled with mitochondria, rough endoplasmic reticulum and Golgi complex at $49.5 \mathrm{~cm}$ CVRL (185 ${ }^{\text {th }}$ day). The nuclei were roughly spherical in shape. Most of the acini were two cell layered with inner prismatic cells and outer cuboidal myoepithelial precursor cells during the development of the gland. The electron dense secretory granules of varying density were distinct with inner homogeneous content in late age groups and their number increased during mid and late foetal age groups (Figs. 2 and 3), which was similar to finding of Yaku in human foetal parotid gland. These electron dense granules were located in supranuclear position along with scattered mitochondria and Golgi complex. 


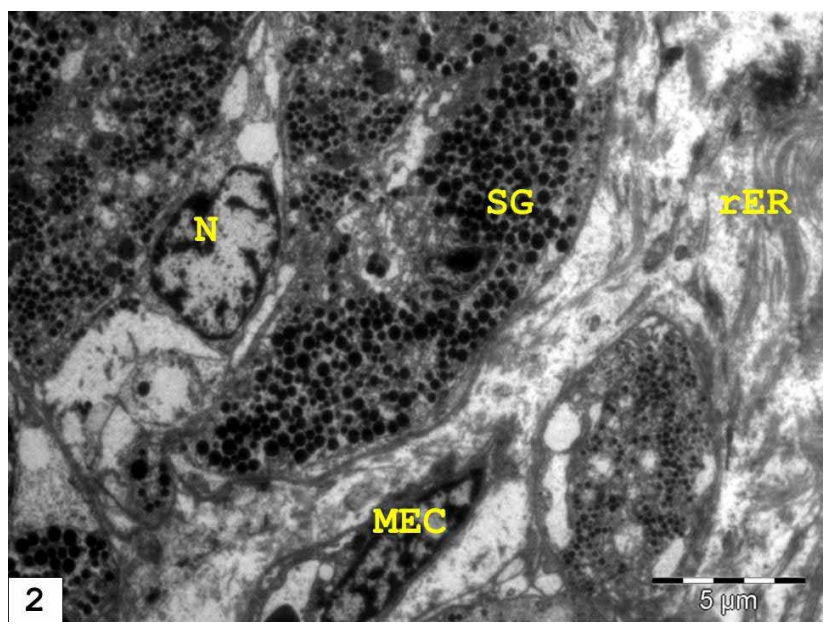

Fig. 2. Transmission electron micrograph of $49.5 \mathrm{~cm} \mathrm{CVRL}\left(185^{\text {th }}\right.$ day) buffalo foetus showing electron dense secretory granules (SG) of varying density. Myoepithelial cell (MEC) is also found during the development of the parotid gland. (N-nucleus; rER-rough endoplasmic reticulum). 1000x

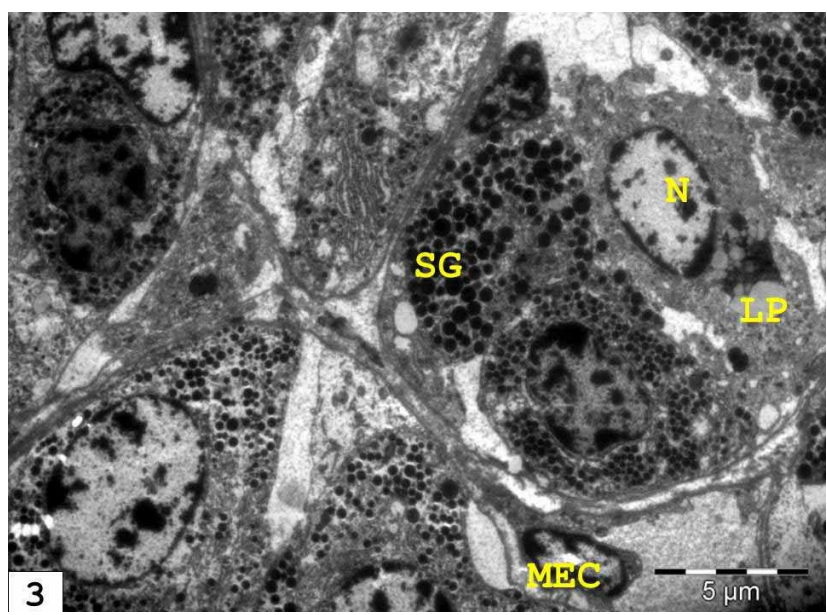

Fig. 3. Transmission electron micrograph of section same as above showing electron dense secretory granules (SG) and myoepithelial cell (MEC) during the development of the parotid gland. (Nnucleus; LP-lipofuchsin pigment). 1000x

Two types of electron dense granules were identified based on granule density viz., dark and light granules. The dark electron dense granules were more in number, whereas light electron dense granules were comparatively less in number having electron lucent content within them (Fig. 4). The mean diameter of dark and light granules was measured about $0.45 \pm 0.1 \mu \mathrm{m}$ and $0.30 \pm 0.1 \mu \mathrm{m}$, respectively which showed that the dark granules were comparatively larger in size.

The mitochondria were numerous, vesicular and supranuclear in position and contained filamentous cristae (Fig. 5). The rough endoplasmic reticulum was compactly

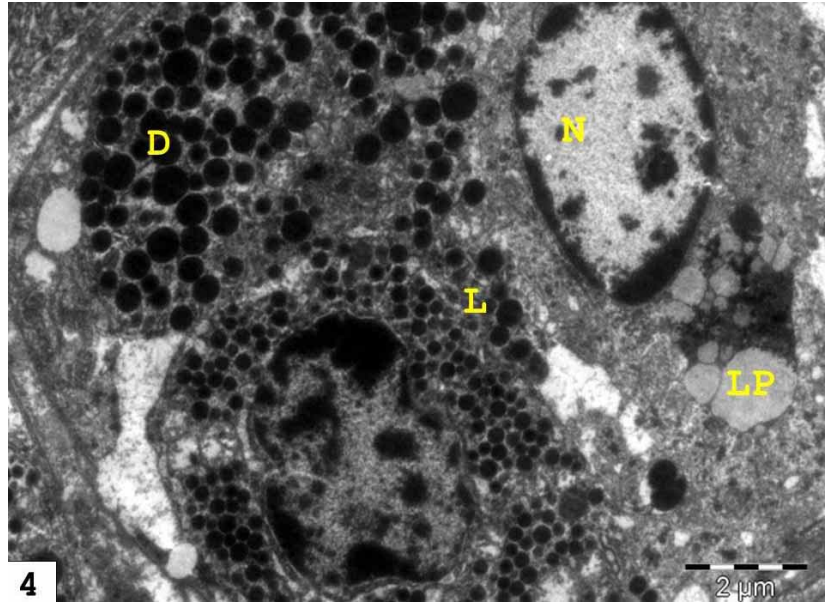

Fig. 4. Transmission electron micrograph of parotid salivary gland of $49.5 \mathrm{~cm}$ CVRL ( $185^{\text {th }}$ day) buffalo foetus showing large dark (D) as well as small light (L) electron dense secretory granules. (N-nucleus; LP-lipofuchsin pigment). 2000x

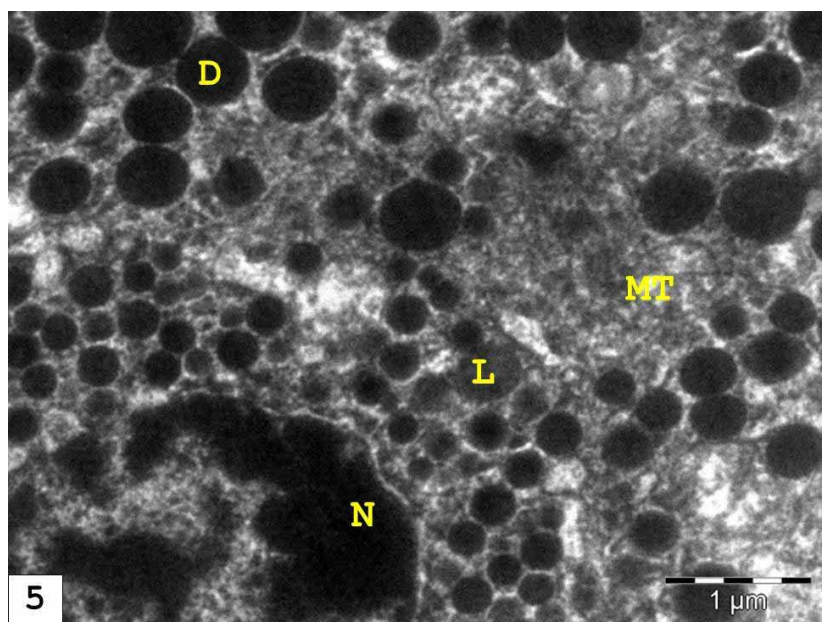

Fig. 5. Transmission electron micrograph of parotid salivary gland of $49.5 \mathrm{~cm}$ CVRL (185 ${ }^{\text {th }}$ day) buffalo foetus showing inner homogeneous content of dark (D) and light (L) electron dense secretory granules. (N-nucleus; MT-mitochondria). 5000x

arranged between vesicular mitochondria. The secretory cells contained moderately dilated cisternae of rough endoplasmic reticulum. The basal lumen showed lateral infoldings close to the adjacent plasmalemma. The basal plasmalemma showed tight junctional complexes with adjacent cell membrane and in certain areas distinct intercellular canaliculi were present between the cells. Numerous microvilli were observed in the apical portion of the cell close to the lumen.

The myoepithelial cells were located at the base of the acinar cell and were stellate shaped. The ultrastructure of myoepithelial cell revealed parallel stream of myofilaments in the cytoplasm and its processes. The nucleus 
occupied most of the cell body region and cytoplasm contained fewer amounts of ribosomes, mitochondria and rough endoplasmic reticulum (Fig. 6). These myoepithelial cells were found to be attached to the glandular cells by desmosomes. Lipofuscin pigments were also observed in between the acinar cells. Similar features were reported in the parotid gland of adult buffalo by Mansouri \& Mehrabi (2000).

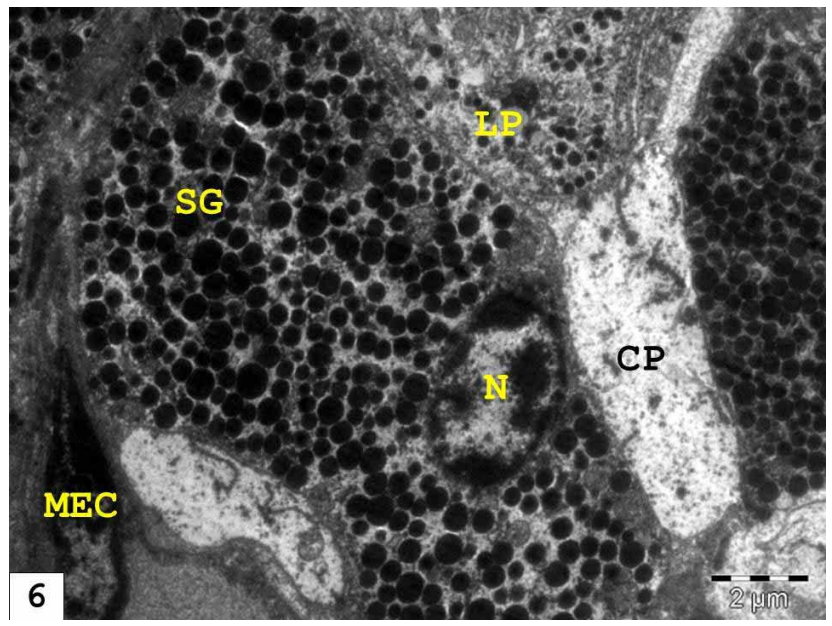

Fig. 6. Transmission electron micrograph of $49.5 \mathrm{~cm}$ CVRL (185th day) buffalo foetus showing myoepithelial cell (MEC) at the base of the acinar cell of parotid gland. (N-nucleus; SG-secretory granules; LP-lipofuchsin pigment; CP-capillary). 1600

The intercalated duct cells appeared cuboidal to low columnar with the broader base. The apical cytoplasm of the epithelial cells lining the intercalated ducts contained secretory granules. Flattened myoepithelial cells with long cytoplasmic processes were observed between the epithelial cells and basement membrane of intercalated ducts, as reported in human beings by Yaku. Mitochondria were few, vesiculated and juxtanuclear in position. Few light and moderate electron dense secretory granules were located close to the lumen. The luminal border of the intercalated duct cells showed cytoplasmic blebs or protrusions from the cell membrane. The larger excretory ducts were composed of 2-3 cell layers with high prismatic and basal cuboidal cells. Similar finding was observed by Young \& Van Lennep (1978) in mammals and (Elewa et al., 2010) in sheep and goat.

\section{CONCLUSIONS}

It may be concluded that the cytoplasm of acinar cells was filled with mitochondria, rough endoplasmic reticulum and Golgi complex in mid and late foetal age groups.
Medium electron dense secretory granules first appeared in the acinar cells of parotid gland at $30 \mathrm{~cm}$ CVRL (141 $1^{\text {st }}$ day). However, at $49.5 \mathrm{~cm}$ CVRL $\left(185^{\text {th }}\right.$ day) two types of electron dense granules were identified on basis of granule density viz., dark and light. The dark electron dense granules were more in number, whereas light granules were comparatively less having electron lucent content within them was identified. The mean diameter of dark and light granules was measured about $0.45 \pm 0.1 \mu \mathrm{m}$ and $0.30 \pm 0.1 \mu \mathrm{m}$, respectively, which showed that the dark granules were comparatively larger in size. The secretory granules were increased in number during the late foetal age group. The myoepithelial cells were located at the base of the acinar cells as well as intercalated and striated ducts, and were stellate in shape. The ultrastructure of myoepithelial cell revealed parallel stream of myofilaments in the cytoplasm and its processes.

\section{ACKNOWLEDGEMENTS}

The specimen preparation, staining and the observations at various magnifications under the transmission electron microscope were done at Electron Microscope Facility, Department of Anatomy, AIIMS, New Delhi (INDIA).

SINGH, A. D. \& SINGH, O. Cambios en el desarrollo de la parótida de búfalo prenatal: Un estudio ultraestructural. Int. J. Morphol., 35(4):1332-1336, 2017.

RESUMEN: El estudio se realizó para elucidar los cambios ultraestructurales en el desarrollo de la parótida del búfalo durante las diferentes etapas de la vida prenatal. Los estudios ultraestructurales revelaron que el citoplasma de las células acinares estaba saturado de mitocondrias, de retículo endoplasmático rugoso y Complexo golgiensis en las edades fetal media y tardía. Se observó un número mayor de gránulos oscuros densos de electrones, mientras que los gránulos ligeros fueron comparativamente menor en número con contenido de electrones. El diámetro medio de gránulos oscuros y ligeros se midió aproximadamente $0,45 \backslash$ pm $0,1 \backslash \mathrm{mu}$ m y $0,30 \backslash \mathrm{pm} 0,1 \backslash \mathrm{mu} \mathrm{m}$, respectivamente, lo que mostró que los gránulos oscuros eran comparativamente mayores en tamaño. Los gránulos secretores aumentaron en número durante el último grupo de edad fetal. Las células mioepiteliales se localizaron en la base de las células acinares, así como en conductos intercalados y estriados, y tenían una forma estrellada. La ultraestructura de las células mioepiteliales reveló una corriente paralela de miofilamentos en el citoplasma y sus procesos. También se observaron pigmentos de lipofuscina entre las células acinares de la glándula parótida.

PALABRAS CLAVE: Búfalo; Microscopía electrónica; Glándula parótida; Prenatal. 


\section{REFERENCES}

Bozolla, J. J. \& Russell, L. D. Electron Microscopy: Principles and Techniques for Biologists. London, Jones and Bartlett Publishers International, 1992. pp.101-3.

Chi, J. G. Prenatal development of human major salivary glands. Histological and immunohistochemical characteristics with reference to adult and neoplastic salivary glands. J. Korean Med. Sci., 11(3):20316, 1996.

Elewa, Y. H.; Bareedy, M. H.; Abuel-Atta, A. A.; Ichii, O.; Otsuka, S.; Kanazawa, T.; Lee, S.; Hashimoto, Y. \& Kon, Y. Structural characteristics of goat (Capra hircus) parotid salivary glands. Jpn. J. Vet. Res., 58(2):121-35, 2010.

Featherstone, J. D. The science and practice of caries prevention. J. Am. Dent. Assoc., 131(7):887-99, 2000.

Knospe, C. \& Böhme, G. Prenatal development of the mandibular gland and parotid gland in cats. Anat. Histol. Embryol., 24(1):1-6, 1995.

Mansouri, S. H. \& Mehrabi, J. Ultrastructural observations on buffalo parotid gland. J. Appl. Anim. Res., 18:215-20, 2000.

Moghaddam, Y. F.; Darvish, J.; Mahdavi, S. N.; Abdulamir, A. S.; Mousavi, M. \& Daud, S. K. Comparative histological and histochemical interspecies investigation of mammalian submandibular salivary glands. Res. J. Appl. Sci., 4:50-6, 2009.

Pospieszny, N.; Kuryszko, J.; Juszczyk, M. \& Adamski, M. Morphological and histological analysis of the mandibular gland and sublingual glands in prenatal period of the pig. Bull. Vet. Inst. Pulawy, 54:351-5, 2010.

Redman, R. S. \& Sreebny, L. M. Proliferative behavior of differentiating cells in the developing rat parotid gland. J. Cell Biol., 46(1):81-7, 1970.

Singh, A. D. \& Singh, O. Prenatal and neonatal development of mandibular salivary gland of Indian buffalo. J. Appl. Anim., Res., 45(1):373-83, 2017.

Singh, A. D.; Sasan, J. S.; John, M. A. \& Choudhury, A. R. Gross and microscopic characterization of the parotid salivary gland of sheep. Indian Vet. J., 92:61-3, 2015.

Soliman, M. K. Studies on the physiological chemistry of the allantoic and amniotic fluids of buffalo at various periods of pregnancy. Indian Vet. J., 52:106-11, 1975.

Wolff, M. S.; Mirels, L.; Lagner, J. \& Hand, A. R. Development of the rat sublingual gland: a light and electron microscopic immunocytochemical study. Anat. Rec., 266(1):30-42, 2002.

Yaku, Y. Ultrastructural studies on the development of human fetal salivary glands. Arch. Histol. Jpn., 46(5):677-90, 1983.

Young, J. A. \& Van Lennep, E. W. The Morphology of Salivary Glands. London, Academic Press, 1978.

\author{
Corresponding author: \\ Dr. Amandeep Singh \\ Assistant Professor \\ Deptt. of Veterinary Anatomy \\ College of Veterinary Sciences \\ LUVAS, Hisar - 125004 \\ Haryana \\ INDIA
}

Email: amanatomy287@gmail.com

Received: 03-03-2017

Accepted: 25-05-2017 